\title{
PRZELLLD SEJMOWY
}

nr 6(161)/2020, s. 33-45; https://doi.org/10.31268/PS.2020.79

MICHAŁ TOMASZ GÓRALCZYK*

\section{Związek między konstytucyjną zasadą spoleczeństwa obywatelskiego a partycypacją społeczną - zarys problematyki}

Rozwój społeczeństwa obywatelskiego wskazywany jest jako jeden z imperatywów współczesnej polityki państw demokratycznych. Jego filarami są partycypacja społeczna i obywatelska oraz samorządność. Aktywność w ramach społeczeństwa obywatelskiego może mieć charakter grupowy bądź przyjmować postać indywidualnej aktywności obywatelskiej, przejawiającej się w postawie i świadomości obywatelskiej jego członków. Społeczeństwo obywatelskie wiąże się z postawami kreatywnymi członków wspólnoty, którzy są uprawnieni do podejmowania decyzji. Ideę społeczeństwa obywatelskiego należy zatem rozumieć jako rzeczywistą możliwość aktywnego udziału obywateli w szeroko rozumianych sprawach publicznych. Administracja publiczna stwarza lub ogranicza istotne warunki uczestnictwa obywateli w budowaniu demokratycznego ładu (lub bezładu) poprzez umożliwienie procesów i działań wchodzących w zakres partycypacji społecznej.

SŁowa KLUCzowe: społeczeństwo obywatelskie, partycypacja społeczna, Konstytucja RP, obywatel, organizacja społeczna, administracja publiczna

\section{The relationship between the constitutional principle of civil society and the social participation - an outline of the issues}

The development of civil society is indicated as one of the imperatives of contemporary politics in democratic states. Its pillars are social and civic participation as well as self-government. Activity within civil society can be group-based or take the form of individual civic activity, manifested in the attitude and civic awareness of its members. Civil society is associated with the creative attitudes of community members who are empowered to make decisions. The idea of civil society should therefore be understood as a real possibility of active participation of citizens in broadly understood public matters. Public administration creates or limits the essential conditions for citizens' participation in building a democratic order (or disorder) by enabling processes and activities that fall within the scope of social participation.

KeY wORDs: civil society, social participation, Polish Constitution, citizen, social organization, public administration

* Mgr Michał Tomasz Góralczyk, Uniwersytet w Białymstoku, Wydział Prawa, Katedra Prawa Konstytucyjnego i Systemów Politycznych, mg.nauka@wp.pl, https://orcid.org/0000-0002-2814-5469 


\section{Wprowadzenie}

W Konstytucji RP jako najwyższym akcie normatywnym w żadnym miejscu nie użyto pojęcia społeczeństwa obywatelskiego, ale w jej licznych sformułowaniach oraz postanowieniach dano wyraz podstawowym elementom wykładni tej właśnie idei. W aspekcie organizacyjnym idea ta opiera się na dwóch założeniach wyjściowych ${ }^{1}$.

Problem badawczy podjęty w niniejszym artykule jest następujący: art. 11, 12, 14, 16, 17, 25, 58 oraz 59 Konstytucji RP z dnia 2 kwietnia 1997 r. nawiązują do zasady pluralizmu politycznego, wolności zrzeszania się w różnego rodzaju organizacje (przede wszystkim w związki zawodowe), wolności prasy oraz innych środków masowego przekazu, samorządu terytorialnego, jak również zawodowego, autonomii, wzajemnej niezależności oraz współdziałania w stosunkach między państwem a kościołami i innymi związkami wyznaniowymi. Czy w rezultacie dokonanej wykładni wymienionych przepisów w kierunku przysługujących obywatelom przywilejów można je przyporządkować do zasady społeczeństwa obywatelskiego?

Udzielając odpowiedzi na tak sformułowane pytanie, posłużono się następującymi metodami badawczymi: metodą obserwacyjną, analizą piśmiennictwa, metodą monograficzną, metodą badania dokumentów, metodą analizy i konstrukcji logicznej oraz technikami heurystycznymi. Wskazując na bardziej szczegółowe zastosowanie procedur badawczych, należy dodać, że zastosowano metodę: dogmatyczno-prawną, teoretyczno-prawną, porównawczo-prawną, komparytystyczną, a także - w pewnym ograniczonym zakresie - historyczno-prawną.

W artykule przyjęto założenie, że, po pierwsze, każdy obywatel funkcjonuje równocześnie w kilku podstawowych układach społecznych, przede wszystkim w układzie politycznym, układzie pracowniczym i układzie terytorialnym. W każdym z nich ma określone interesy oraz dążenia i w dowolnym $\mathrm{z}$ nich powinien dysponować instrumentami pozwalającymi mu na ich wyrażenie oraz realizację. Po drugie, założono, że owe interesy oraz dążenia z natury są zróżnicowane, a często przeciwstawne. Stąd proces ich wyrażania musi mieć pluralistyczny charakter, polegający na możliwości równoległego formułowania konkurencyjnych programów i tworzeniu organizacji sprzyjających ich realizacji ${ }^{2}$. Społeczeństwo obywatelskie to społeczeństwo pluralistyczne, w którym każdy ma możliwość działania w wybranych przez siebie organizacjach oraz strukturach służących realizacji jego podmiotowości jako obywatela, pracownika czy mieszkańca ${ }^{3}$.

„Zasada społeczeństwa obywatelskiego stanowi punkt wyjścia do innych zasad konstytucyjnych, zwłaszcza zasady pluralizmu politycznego (art. 11), wolności

${ }^{1}$ L. Garlicki, Polskie prawo konstytucyjne. Zarys wyktadu, Warszawa 2012, s. 66. Confer Konstytucja Rzeczypospolitej Polskiej z dnia 2 kwietnia 1997 r., Dz.U. nr 78, poz. 483, ze zm. [dalej: Konstytucja RP].

${ }^{2}$ L. Jaworski, Wolność prasy i innych środków społecznego przekazu jako zasada ustrojowa Rzeczypospolitej Polskiej, „Zarządzanie Mediami” 2014, t. 1, nr 1, s. 9-10. Vide także L. Garlicki, op. cit., s. 66.

${ }^{3}$ R. Piotrowski, P. Ochmann, M. Pisz, Prawo konstytucyjne. Kompendium, Warszawa 2014, s. 11. 
zrzeszania się w różnego rodzaju organizacje społeczne (art. 12), głównie w związki zawodowe (art. 12 oraz art. 59 ust. 1), wolności prasy oraz innych środków masowego przekazu (art. 14), zasady samorządu terytorialnego i zawodowego (art. 16 i 17), deklarowanej w preambule zasady pomocniczości, a także zasady autonomii, wzajemnej niezależności i współdziałania w stosunkach między państwem a kościołami i innymi związkami wyznaniowymi (art. 25)"'4.

Biorąc pod uwagę demokrację partycypacyjną, należy zaznaczyć, że podział władzy (wpływu) między uczestników partycypacji nie jest równomierny, jest zaś stały, a co za tym idzie - siła oddziaływania stron na proces decyzyjny nie jest taka sama $^{5}$. Te wzajemne relacje mogą przybierać formę nieinteraktywną bądź interaktywną. W przypadku tej pierwszej mamy do czynienia głównie z jednokierunkowymi formami uczestnictwa, zapewniającymi członkom społeczności lokalnych co najwyżej odbiór informacji o bieżących zamierzeniach władz, a także bierne konsultacje przyszłych zamierzeń.

Druga z wymienionych form przewiduje już możliwość zgłaszania propozycji rozwiązania danego problemu, a także inicjowania oraz realizacji konkretnych działań ${ }^{6}$. Trzeba tu jednak dokonać wydzielenia niektórych (legalnych i nielegalnych) form aktywności obywatelskiej, jak choćby strajki, protesty, demonstracje, okupacja instytucji publicznych itp. Niewątpliwie są one ważnym narzędziem w ręku demokratycznego społeczeństwa, nie urzeczywistniają jednak uczestnictwa w znaczeniu będącym przedmiotem niniejszych rozważań ${ }^{7}$.

\section{Norma społeczeństwa obywatelskiego w różnych ujęciach konstytucyjnych — aspekt porównawczy}

Przez społeczeństwo cywilne rozumie się pozapaństwową sferę samodzielnej aktywności gospodarczej i kulturalnej zarówno jednostek (osób fizycznych), jak i osób prawnych. Warunkiem tej aktywności jest autonomia woli, a także wolności oraz prawa przysługujące działającym podmiotom ${ }^{8}$. Sposób rozumienia pojęcia społeczeństwa obywatelskiego jest jednak bardzo różny. Zdarza się (wcale nierzadko), że tym pojęciem

${ }^{4}$ K. Prokop, Podstawowe zasady ustrojowe, [w:] Prawo konstytucyjne, red. S. Bożyk, Białystok 2014, s. 81. Vide szerzej Konstytucja RP.

5 A. Potoczek, Zaufanie społeczne a proces partycypacji, „Animacja Życia Publicznego. Analizy i Rekomendacje" 2011, nr 2, s. 5.

${ }^{6}$ Vide P. André, B. Enserink, D. Connor, Public Participation. International Best Practice Principles, IAIA Special Publication Series, nr 4, Fargo 2006, s. 52-53.

7 M. Kalisiak-Mędelska, Public Participation in the Municipalities of Polish Voivodeships. A Presentation of the Research Findings, [w:] Social and Economic Development and Regional Politics: Space in a Time of Economic Change, red. P. Hlavacek, P. Olsova, Ústí nad Labem 2013, s. 47.

8 Vide A. Rzepliński, Wrowadzenie, [w:] Prawa człowieka w społeczeństwie obywatelskim, red. A. Rzepliński, Warszawa 1993, s. 8-9. 
obejmuje się nie tylko autonomiczną oraz niezależną od państwa aktywność gospodarczą i kulturalną obywateli, ale także udział obywateli w sprawowaniu władzy państwowej. W takim ujęciu partie polityczne uważa się za ważne organizacje społeczeństwa obywatelskiego. Inaczej mówiąc, nie widzi się różnicy między zasadą społeczeństwa obywatelskiego a samą zasadą pluralizmu politycznego9.

Częściej jednak ideę społeczeństwa obywatelskiego pojmuje się węziej, czego dowodzić może dyskusja, która toczyła się wewnątrz Komisji Konstytucyjnej Zgromadzenia Narodowego ${ }^{10}$. Dla Alicji Grześkowiak ideę społeczeństwa obywatelskiego wyrażał art. 7 senackiego projektu konstytucji, w którym mowa była o pluralizmie politycznym i wpływaniu na politykę państwa ${ }^{11}$.

Według Jerzego Jaskierni i zdecydowanej większości komisji właściwym rozwiązaniem było odrębne sformułowanie zasad pluralizmu politycznego, a także społeczeństwa obywatelskiego. Jak wyjaśniał Witold Osiatyński, w przepisie o społeczeństwie obywatelskim nie chodzi o wpływanie na politykę państwa, lecz o inne formy i cele działania. W odniesieniu do społeczeństwa obywatelskiego przyjęto sformułowanie obecnego art. 12 Konstytucji RP, a partiom politycznym poświęcono art. $11^{12}$.

Wiele najnowszych konstytucji przywołuje ideę społeczeństwa obywatelskiego już w samej preambule ${ }^{13}$, inne w tekście głównym, niekoniecznie przez użycie tego pojęcia, tak jak jest to w polskiej konstytucji, której art. 12 ma następującą treść: „Rzeczpospolita Polska zapewnia wolność tworzenia i działania związków zawodowych, organizacji społeczno-zawodowych rolników, stowarzyszeń, ruchów obywatelskich, innych dobrowolnych zrzeszeń oraz fundacji”. Znaczenie art. 12 w szczególny sposób podkreślają słowa wstępu do konstytucji o ,zasadzie pomocniczości umacniającej uprawnienia obywateli i ich wspólnot". O ile w polskiej konstytucji zasadę społeczeństwa obywatelskiego wyrażono w sposób opisowy, o tyle w kilku innych konstytucjach państw postsocjalistycznych przywołano wprost tę ideę, najczęściej w preambule (konstytucje Czech, Litwy i Macedonii) ${ }^{14}$. Koncepcja społeczeństwa obywatelskiego została inaczej ujęta w Konstytucji Bułgarii, której art. 4 ust. 2 stanowi: „Republika Bułgarii gwarantuje życie, godność i prawa jednostki oraz stwarza warunki swobodnego rozwoju człowieka

${ }^{9}$ A. Pułło, Zasady ustroju politycznego państwa. Zarys wykladu, Gdańsk 2014, s. 171-172.

${ }^{10}$ Komisja Konstytucyjna Zgromadzenia Narodowego została utworzona w ramach ustawy konstytucyjnej z dnia 23 kwietnia 1992 r. o trybie przygotowania i uchwalenia Konstytucji Rzeczypospolitej Polskiej, Dz.U. nr 67, poz. 336, ze zm.

${ }^{11}$ „Partie polityczne, ruchy obywatelskie i inne ugrupowania obywateli działające w oparciu o zasadę pluralizmu politycznego, są formą dobrowolnego, a także równego uczestnictwa politycznego w kształtowaniu się, a także wyrażaniu woli obywateli oraz wpływania na samą politykę państwa". Vide szerzej A. Pułło, op. cit., s. 172.

${ }^{12}$ Confer w szczególności A. Pułło, op. cit., s. 171-172.

${ }^{13}$ Vide np. Konstytucja Republiki Litewskiej: „Naród Litwinów [...], dążąc do stworzenia otwartego, sprawiedliwego, żyjącego w zgodzie społeczeństwa obywatelskiego i państwa prawa, [...]” (Konstytucja Republiki Litewskiej z dnia 25 października 1992 r., thum. H. Wisner, Warszawa 2006). Confer A. Pułło, op. cit., s. 172.

${ }^{14}$ Vide szerzej A. Pułło, op. cit., s. 172. 
i społeczeństwa obywatelskiego"15. W innych konstytucjach natomiast nie występuje deklaracja społeczeństwa obywatelskiego przedstawiona w jakiejkolwiek formie we wstępie czy rozdziale o zasadach ustrojowych.

Można jednak stwierdzić, że zasadę społeczeństwa obywatelskiego wyrażają implicite wszystkie te postanowienia konstytucji z rozdziałów o prawach jednostki, które gwarantują wolność zrzeszania się. Tak było i jest w ogromnej większości konstytucji państw demokratycznych. Dotyczy to nie tylko ustaw zasadniczych powstałych w czasach, w których nie przywiązywano większej wagi do wysłowienia najważniejszych zasad już na początku tekstu, ale także wielu późniejszych konstytucji, w których zaczęto zwracać uwagę na koncepcje ujęte we wstępie ${ }^{16}$.

Niemała liczba konstytucji albo w ogóle nie posiada rozdziału o zasadach ustrojowych (Konstytucja Islandii z 1944 r., Konstytucja Belgii z 1994 r. ${ }^{17}$ ), albo jest on w swej treści bardzo ograniczony (Konstytucja Danii z 1953 r., Konstytucja Grecji z 1975 r.). Wiele konstytucji, jak te wymienione w poprzednim zdaniu, nie posiada bowiem także preambuły, która wskazywałaby na jakiekolwiek wartości czy zasady ustrojowe. Część konstytucji państw zachodnich posiada jednak rozwinięte rozdziały ogólne, mimo to trudno w nich odnaleźć przepisy, które można by uznać za wyrażające zasadę ochrony społeczeństwa obywatelskiego ${ }^{18}$. Nie oznacza to, że nie można formułować tej zasady na tle przepisów gwarantujących wolność zrzeszania się, które kiedyś ze zrozumiałych powodów umieszczano jeśli nie w odrębnych deklaracjach praw, to w rozdziałach nawiązujących do samej wolności jednostki. Należy dodać, że rzadko kiedy ambicją twórców konstytucji było ustalanie w rozdziałach ogólnych wszystkich głównych zasad ustroju państwa ${ }^{19}$.

\section{Analiza podstaw prawnych dzialalności organizacji spolecznych zrzeszających obywateli}

Zasada społeczeństwa obywatelskiego wymaga ponadto, by obok systemu partii politycznych mogły działać także inne organizacje zrzeszające obywateli, tworzone dla realizacji ich najróżniejszych interesów i dążeń. Podstawowym celem tych organizacji

${ }^{15}$ Confer Konstytucja Republiki Butgarii z dnia 12 lipca 1991 r., thum. H. Karpińska, [w:] Konstytucje świata, red. K. Gralak, Warszawa 2012, s. 53.

16 A. Pułło, op. cit., s. 172-173.

17 Tekst pierwotny Konstytucji Belgii pochodzi z 7 lutego 1831 r. i był wielokrotnie nowelizowany w XIX, a także XX w. Aktualny tekst stanowił przedmiot dyskusji w Izbie Reprezentantów 19 i 20 stycznia 1994 r. oraz w Senacie 2 i 3 lutego 1994 r. Ogłoszony został w „Monitorze Belgii” (Belgisch Staatsblad - Moniteur Belge) w nr 35 z dnia 17 lutego 1994 r. w trzech językach: niderlandzkim, francuskim oraz niemieckim. Podstawę niniejszego przekładu konstytucji stanowił tekst ujęty w języku francuskim. Confer Konstytucja Belgii z dnia 14 lutego 1994 r., thum. W. Skrzydło, Warszawa 1996.

18 Vide A. Pułło, op. cit., s. 173.

19 Vide szerzej A. Pułło, op. cit., s. 173. 
nie jest zdobywanie samej władzy politycznej (bo wtedy stawałaby się one partiami politycznymi), natomiast — w zależności od swego programu oraz charakteru — organizacje te mogą oddziaływać na proces podejmowania decyzji politycznych. Wówczas postrzegać je należy jako część składową systemu grup interesów stanowiących tło dla funkcjonowania partii politycznych ${ }^{20}$.

Konstytucja RP ogranicza się do ogólnej gwarancji wolności zrzeszania się (art. 12 i art. 58), z tym jednak, że zakazy ustanowione w art. 13 konstytucji odnoszą się także do omawianych organizacji. Podstawową prawną formą funkcjonowania tych organizacji jest stowarzyszenie, a sposób ich powstawania i działania, jak również formy kontroli nad nimi określa ustawa z dnia 7 kwietnia 1989 r. - Prawo o stowarzyszeniach $^{21}$.

Przepis art. 12 Konstytucji RP ustanawia zasadę pluralizmu społecznego oraz odwołuje się do idei społeczeństwa obywatelskiego. Istotą pluralizmu społecznego jest swoboda tworzenia i działania rozmaitego typu zrzeszeń, których celem ma być reprezentacja wobec organów władzy publicznej i - kiedy to niezbędne - obrona zróżnicowanych interesów społeczno-ekonomicznych obywateli ${ }^{22}$. Konstytucja wymienia z nazw rodzajowych związki zawodowe, będące organizacjami reprezentującymi interesy pracowników najemnych (confer też art. 59), oraz organizacje społeczno-zawodowe rolników, co dotyczy głównie rolników indywidualnych. Ponadto wymienia ogólnie stowarzyszenia, ruchy obywatelskie, jak również ,inne dobrowolne zrzeszenia" ${ }^{\prime 3}$.

Zrzeszenie (związek bądź stowarzyszenie) skupia na zasadzie dobrowolności ludzi w odniesieniu do stałego działania podjętego, aby wspólnie realizować wybrane cele lub móc zaspokajać określone potrzeby. Wolność zrzeszania się obejmuje przede wszystkim wolność tworzenia zrzeszeń oraz przynależności do nich. Przepis art. 58 Konstytucji RP realizuje i rozwija postanowienie art. 12. Natomiast art. 58 ust. 3 Konstytucji RP przewiduje istnienie różnego rodzaju zrzeszeń. Te, które podlegać mają obowiązkowej rejestracji, określa ustawa Prawo o stowarzyszeniach. A contrario wnosić więc trzeba, że ustawa ta może dopuszczać istnienie zrzeszeń niepodlegających rejestracji, które jednocześnie nie będą podlegały nadzorowi (confer art. 58 ust. 3 in fine) $)^{24}$. Dla przykładu są to m.in. stowarzyszenia zwykłe, stowarzyszenia kultury fizycznej, uczniowskie kluby sportowe oraz kluby sportowe, które nie prowadzą działalności gospodarczej. Ustawa regulować ma też sam tryb takiej rejestracji, przy czym organem rejestrowym jest sąd ${ }^{25}$. Sąd może odmówić rejestracji zrzeszenia, którego cel jest sprzeczny z Konstytucją RP (confer

20 L. Garlicki, op. cit., s. 68.

21 Dz.U. z 2019 r. poz. 713, ze zm. Vide szerzej A. Pułł, op. cit., s. 173.

22 Confer art. 58 i art. 59 Konstytucji RP.

${ }^{23}$ Confer P. Winczorek, Komentarz do Konstytucji Rzeczypospolitej Polskiej z dnia 2 kwietnia 1997 r., Warszawa 2000, s. 24.

24 Vide szerzej ibidem, s. 79.

25 Vide art. 58 ust. 2 zd. 2 Konstytucji RP. 
np. jej art. 13) lub ustawą określającą status prawny zrzeszenia danego typu czy też jakąkolwiek inną ustawą (np. karną26).

Nadzór nad zrzeszeniami polega na kontroli ich działania, jak również na możliwości podejmowania wobec nich środków prawnych w przypadku stwierdzenia niezgodności tego działania z Konstytucją RP bądź ustawami. Ostatecznym środkiem nadzoru może być zakaz działalności zrzeszenia orzeczony przez sąd. Zakaz działalności zrzeszenia nie zamyka drogi do indywidualnej odpowiedzialności (cywilnej czy karnej) jego członków - w tym zwłaszcza członków kierownictwa — za własne działania podejmowane $w$ ramach i pod szyldem zrzeszenia ${ }^{27}$.

Wolności, o których mowa w art. 58 Konstytucji RP, mogą ulec ograniczeniu tylko w stanie wojennym lub wyjątkowym ${ }^{28}$. Związki określone w tym przepisie są bowiem szczególnym rodzajem zrzeszeń. Na tle innych zrzeszeń wyróżnia je cel, dla którego zostały powołane. Do związków wymienionych w art. 58 Konstytucji RP należą reprezentacje społeczno-zawodowych i ekonomicznych interesów ${ }^{29}$ pracowników najemnych (tj. związki zawodowe) ${ }^{30}$, rolników ${ }^{31}$ oraz pracodawców ${ }^{32}$. Konstytucja RP traktuje te trzy typy związków na równym poziomie. Ma to istotne znaczenie w odniesieniu do związków zawodowych z jednej strony, jak i do związków pracodawców z drugiej. Są one bowiem głównymi partnerami dialogu społecznego, o którym mowa w preambule i art. 20 Konstytucji RP. Wolność zrzeszania się w związki zawodowe, społeczno-zawodowe organizacje rolników, jak również związki pracodawców konstytuuje prawnie pluralistyczne społeczeństwo obywatelskie (confer art. 12 Konstytucji RP) ${ }^{33}$.

Organizacje wymienione w art. 12 Konstytucji RP w języku politycznym oraz w publicystyce nazywane są bardzo często organizacjami pozarządowymi ${ }^{34}$. Angielskie określenie $N G O$ (Non-governmental Organizations ${ }^{35}$ ) pojawiło się w piśmiennictwie w latach czterdziestych XX w. Mniej lub bardziej zbliżone do niego są pojęcia non-profit organizations oraz independent organizations ${ }^{36}$.

${ }^{26}$ Vide szerzej ustawa z dnia 6 czerwca 1997 r. — Kodeks karny, Dz.U. z 2020 r. poz. 1444, ze zm.

27 P. Winczorek, op. cit., s. 79-80.

28 Vide art. 233 ust. 1 Konstytucji RP.

${ }^{29}$ Confer P. Winczorek, op. cit., s. 80. Vide także L. Garlicki, op. cit., s. 66-70.

30 Vide ustawa z dnia 23 maja 1991 r. o związkach zawodowych, Dz.U. z 2019 r. poz. 263.

31 Vide ustawa z dnia 7 kwietnia 1989 r. o związkach zawodowych rolników indywidualnych, Dz.U. z 2019 r. poz. 210.

32 Vide ustawa z dnia 23 maja 1991 r. o organizacjach pracodawców, Dz.U. z 2019 r. poz. 1809.

33 Confer P. Winczorek, op. cit., s. 80. Vide także L. Garlicki, op. cit., s. 66-70.

34 Zastrzeżenia można mieć do samego terminu ,organizacje pozarządowe”. Jak zauważał Jerzy Ciemniewski, wyróżnienie pojęcia organizacji pozarządowych ma sens na arenie międzynarodowej, ale gdzie indziej jest to zupełnie nietrafne. „Nie wiem — dodawał — jakie organizacje rządowe mielibyśmy w państwie. Organizacje rządowe działające w państwie nazywają się po prostu jego organami”. Confer „Biuletyn Komisji Konstytucyjnej Zgromadzenia Narodowego” 1995, nr XIV, s. 23.

${ }^{35}$ Organizacja działająca na rzecz wybranego interesu oraz niedziałająca w celu osiągnięcia zysku.

T. Davies, NGOs: A New History of Transnational Civil Society, Oxford 2014, s. 125-127.

36 A. Pułł, op. cit., s. 174-175. Confer też ibidem, s. 173. 


\section{Związek między regułą społeczeństwa obywatelskiego a partycypacją społeczną}

Społeczeństwo obywatelskie to społeczeństwo, w którym działalność niezależnych od państwa instytucji, organizacji oraz związków i stowarzyszeń różnego rodzaju (a więc właśnie partycypacja społeczna) jest podstawą samodzielnego rozwoju obywateli oraz stanowi wyraz ich osobistej aktywności.

Społeczeństwo obywatelskie powinno wykazywać następujące cechy: suwerenem władzy jest tylko naród sprawujący ją przez swoich przedstawicieli bądź bezpośrednio. Władza działa w granicach oraz na podstawie prawa. System źródeł prawa uwzględnia interesy obywateli. Istnieje prawny system ochrony praw oraz wolności obywateli. Funkcjonują instytucje gwarantujące przede wszystkim przestrzeganie praw (np. powszechnie dostępne sądownictwo właściwe we wszystkich sprawach z wyjątkiem spraw ustawowo zastrzeżonych dla właściwości innych sądów, trybunały czy ombuds$\operatorname{man}^{37}$ ). Obywatele mają faktycznie zapewnioną możliwość uczestniczenia w życiu społecznym - istnieją prawne gwarancje tworzenia i swobodnej działalności organizacji wyrażających interesy obywateli, a organizacje te aktywnie korzystają z tych możliwości. Wszystkie z wymienionych powyżej cech są de facto gwarantem partycypacji społecznej sensu largo ${ }^{38}$.

Trybunał Konstytucyjny w uzasadnieniu wyroku z 27 maja 2003 r. wskazał na duże znaczenie idei społeczeństwa obywatelskiego w partycypacji społecznej: ,społeczeństwo kształtujące się od 1989 roku to społeczeństwo wolnych, świadomych, aktywnych i zaangażowanych w sprawy publiczne obywateli. Obywatele nie mają żadnych przeszkód prawnych organizowania się w sposób odpowiadający ich potrzebom, celom i interesom. Nie ma takiego elementu życia publicznego, w którym nie uczestniczą obywatele zorganizowani w organizacjach społecznych, stowarzyszeniach czy fundacjach" 39 .

Podstawą organizacji społeczeństwa obywatelskiego jest konstytucyjna zasada pomocniczości. Zasada ta została najpełniej wyrażona w encyklice Piusa XI Quadragesimo Anno: „Co jednostka z własnej inicjatywy i własnymi siłami może zdziałać, tego jej nie wolno wydzierać na rzecz społeczeństwa; podobnie niesprawiedliwością, szkodą społeczną i zakłóceniem ustroju jest zabieranie mniejszym i niższym społecznościom tych zadań, które mogą spełnić, i przekazywanie ich społecznościom większym i wyższym.

${ }^{37}$ Samodzielny, centralny organ państwowy, zajmujący się przede wszystkim ochroną praw jednostki, powiązany bezpośrednio z parlamentem i z reguły wybierany przez parlament. Wysłuchuje skarg obywateli na nieprawidłowe działanie administracji i podejmuje działania w celu ich wyeliminowania. Informuje parlament o stanie praworządności w działaniu administracji. Confer A. Domańska, Pozycja ustrojowo-prawna Rzecznika Praw Obywatelskich, Łódź 2013, s. 28.

${ }^{38}$ Vide szerzej D.R. Kijowski, Partycypacja obywatelska w samorzadowych procesach decyzyjnych zagadnienia ogólne, „Samorząd Terytorialny” 2010, nr 1-2, s. 10.

39 Vide wyrok Trybunału Konstytucyjnego z 27 maja 2003 r., sygn. akt K 11/03, OTK, nr 5A, poz. 43. 
Każda akcja społeczna ze swego celu i ze swej natury ma charakter pomocniczy; winna pomagać członkom organizmu społecznego, a nie niszczyć ich lub wchłaniać"40. Z zasady tej wynika przede wszystkim, że organy państwa nie powinny ingerować tam, gdzie małe wspólnoty mogą działać efektywnie. Powinny natomiast umożliwiać w ramach partycypacji społecznej wypełnianie naturalnych zadań przez jednostki i mniejsze społeczności oraz chronić podmiotowość społeczeństwa ${ }^{41}$.

Ingerencja państwa, administracji państwowej na ogół niszczy wartości dobra wspólnego, ogranicza zaangażowanie i aktywność małych grup i jednostek, ich współuczestnictwo oraz odpowiedzialność za bieg spraw publicznych. Tłumi aktywność społeczności lokalnych, ogranicza rozwój organizacji obywatelskich, utrudnia budowanie społeczeństwa obywatelskiego zgodnie z zasadami partycypacji społecznej. Administracja publiczna może sprzyjać procesom upodmiotowienia społeczeństwa, ale może też istotnie te procesy hamować. Decentralizacja i samorządność prowadzić mają do budowania więzi, poczucia przynależności - do kształtowania tożsamości społeczności lokalnych, a także do tworzenia społeczeństwa obywatelskiego ${ }^{42}$.

Rolę organizacji obywatelskich w rozwoju społeczeństwa obywatelskiego należy rozpatrywać w kontekście procesów decentralizacji państwa. Wynika ona w głównej mierze z utrwalonej tradycji, dominującej orientacji ideologicznej, doświadczeń, cenionych wartości, charakteru władzy państwowej, jak również poziomu rozwoju organizacji obywatelskich ${ }^{43}$.

Organizacje obywatelskie jako element partycypacji społecznej mogą być w różnym stopniu sformalizowane i powiązane rozmaitymi zależnościami z podmiotami państwowymi. Niski poziom formalizacji daje większy zakres swobody działania, ale sprzyja tworzeniu stosunkowo nietrwałej struktury. Wysoki poziom formalizacji utrwala strukturę organizacji, ale może ograniczać swobodę działania społeczeństwa obywatelskiego. Warunkiem powstania i rozwoju organizacji obywatelskich jest aktywność jednostek i grup społecznych rozumiana jako ich udział w określaniu celów organizacji, zasad, metod oraz form działania, a także tworzenie warunków do działania i uczestnictwo w zorganizowanych działaniach. Inspirowanie oraz organizowanie aktywności obywatelskiej jest tu środkiem działania ${ }^{44}$. Dopóki nie uda się przełamać powyższych stereotypów i organizacje pozarządowe nie będą traktowane jak równoprawny partner administracji

40 Vide Pius XI, Encyklika Quadragesimo Anno, [w:] Dokumenty nauki społecznej Kościoła, cz. 1, red. K. Radwan, L. Dyczewski, A. Stanowski, Lublin 1987, s. 154. Vide szerzej ibidem, rozdział 5: Odnowienie ustroju społecznego, pkt 79, s. 154-157.

${ }^{41}$ Confer K. Ostaszewski, Partycypacja społeczna w procesie podejmowania rozstrzygnięć w administracji publicznej, Lublin 2013, s. 43.

${ }^{42}$ Vide szerzej M. Tabernacka, Bezpośredni udziat obywateli w ksztattowaniu rozstrzygnięć władz publicznych w postepowaniu mediacyjnym $w$ sferze administracji publicznej jako element funkcjonowania społeczeństwa obywatelskiego, [w:] Prawna działalność instytucji społeczeństwa obywatelskiego, red. J. Blicharz, J. Boć, Wrocław 2009, s. 625 i n.

${ }^{43}$ K. Ostaszewski, op. cit., s. 44.

${ }^{44}$ Confer M. Tabernacka, op. cit., s. 626-627. Vide także K. Ostaszewski, op. cit., s. 44. 
publicznej, dopóty nie będziemy mogli mówić o istnieniu społeczeństwa obywatelskiego funkcjonującego zgodnie z zasadami partycypacji społecznej w Polsce.

Dynamiczny proces rozwoju sektora non-profit jest jednym z najważniejszych osiągnięć wolnej Polski. Zgodnie z opinią wielu komentatorów polskiej demokracji do pełnego sukcesu brakuje nam jednak przemiany mentalności społeczeństwa ${ }^{45}$. Społeczeństwo obywatelskie poprzez stosowanie instrumentów wchodzących w zakres partycypacji społecznej stanowi obszar działania instytucji oraz grup społecznych rozciągający się między rodziną, państwem oraz rynkiem ${ }^{46}$.

Konstytucja RP wymienia podstawowe, dotychczas utrwalone wśród społeczeństwa formy organizowania się, a jednocześnie deklaruje wolność tworzenia „innych dobrowolnych zrzeszeń" $w$ ramach proklamowanej wolności zrzeszania się (art. 58 ust. 1) ${ }^{47}$. Wskazuje na to uchwała Naczelnego Sądu Administracyjnego z 12 grudnia 2005 r.: „Analiza cech poszczególnych organizacji wymienionych w art. 12 Konstytucji RP prowadzi do następujących wniosków: po pierwsze, Konstytucja zakłada różnorodność form organizacyjnych realizacji prawa do zrzeszania się obywateli, a wyliczenie organizacji w art. 12 Konstytucji RP nie jest wyczerpujące. Po drugie, wszystkie organizacje wymienione w art. 12 Konstytucji RP mają co najmniej 5 cech wspólnych, które można uznać za minimalny zespół cech charakteryzujących je razem: są to organizacje obejmujące wyodrębniony zespół osób, oparte na dobrowolności przynależności do nich. Do organizacji tych odnosi się właściwy zespół przepisów określających strukturę, zakres praw oraz obowiązków. Działalność i cele organizacji określone są przede wszystkim statutem i muszą pozostawać w zgodzie z celami państwa. Organy tych organizacji pochodzą z wyboru tych, którzy te organizacje tworzą. Organizacje pozostają pod kontrolą lub nadzorem organów samej władzy publicznej"48.

Należy podkreślić znaczenie aktywnych, świadomych oraz uczestniczących w różnych formach partycypacji społecznej obywateli dla samego społeczeństwa obywatelskiego. To właśnie oni urzeczywistniają podstawowe zasady oraz wartości demokratycznego ładu społecznego, a tworząc aktywne wspólnoty, budują instytucjonalne podstawy swoich działań. Poza wskazanymi wcześniej organizacjami mogą oni działać również w ramach wolontariatu, który jest bardzo ważną formą wciąż kształtującego się społeczeństwa obywatelskiego oraz jednym z ważniejszych przejawów partycypacji społecznej ${ }^{49}$.

Umożliwienie obywatelom sprawowania władzy nie tylko za pośrednictwem swoich przedstawicieli, ale też poprzez partycypację społeczną ma pomóc $\mathrm{w}$ budowie społeczeństwa obywatelskiego. W demokracji nie chodzi tylko o obywatela biernego, który raz na jakiś czas oddaje swój głos, a opuszczając lokal wyborczy, schodzi ze sceny politycznej

45 Vide Indeks spoleczeństwa obywatelskiego w Polsce 2005, Warszawa 2006, s. 27.

${ }^{46}$ P. Frączak, M. Rogaczewska, K. Wygnański, Głos $w$ dyskusji na temat wizji rozwoju społeczeństwa obywatelskiego w Polsce, Warszawa 2005, s. 27-28.

47 Confer M. Tabernacka, op. cit., s. 628.

48 Vide uchwała Naczelnego Sądu Administracyjnego z 12 grudnia 2005 r., sygn. akt II OPS 4/05, ONSA 2006, nr 2, poz. 37.

49 Vide szerzej K. Ostaszewski, op. cit., s. 46-49. 
(aż do następnego głosowania), ale przede wszystkim o zaangażowanie społeczeństwa w sprawy publiczne. Społeczeństwo obywatelskie jest czynnikiem determinującym partycypację społeczną i prawdziwy demokratyczny system. Łagodzenie napięć, które generują się w demokratycznych społeczeństwach, wymaga współdziałania państwa, żeby to powstałe społeczeństwo obywatelskie (civil society) nie przekształciło się w uncivil society $^{50}$.

\section{Konkluzje}

Współczesne odrodzenie refleksji na temat społeczeństwa obywatelskiego jest próbą przeciwdziałania niedostatkom partycypacji społecznej. Bezdyskusyjną kwestią dla wielu dzisiejszych badaczy pozostaje przekonanie głoszone od czasów Alexisa de Tocqueville'a, że społeczeństwo obywatelskie jest naturalnym zapleczem demokracji partycypacyjnej. Partycypacja społeczna bez społeczeństwa obywatelskiego nie funkcjonuje dobrze, gdyż dla prawidłowego działania tego systemu niezbędny jest kapitał społeczny, zaufanie, wola współpracy, a także znajomość spraw publicznych. Wymienione cechy są charakterystyczne właśnie dla społeczeństwa obywatelskiego ${ }^{51}$. Co należy również podkreślić, partycypacja społeczna jest procesem, który zachodzi w sposób obiektywny, niezależnie od przekonań i postaw osób sprawujących funkcje publiczne, osób odpowiedzialnych za tworzenie prawa oraz jednostek wchodzących w skład społeczeństwa obywatelskiego ${ }^{52}$.

Podsumowując powyższe rozważania, należy stwierdzić, że społeczeństwo obywatelskie „,nie działa w opozycji do samego demokratycznego państwa, ale współpracuje z nim" "s3. W kontekście trwającego rozwoju partycypacji społecznej w Polsce należy pamiętać o potrzebie wykreowania funkcjonalnego społeczeństwa obywatelskiego, które będzie partnerem rządu w rozwiązywaniu problemów. Warto także uzmysłowić rządzącym, że powinni oni pomagać w powstaniu aktywnego, świadomego swoich praw społeczeństwa ${ }^{54}$. Taka sytuacja może tylko wzmocnić państwo, gdyż prawidłowe

50 Vide Ł. Stach, Społeczeństwo obywatelskie Johna Keane’a, [w:] Czas społeczeństwa obywatelskiego. Między teoria a praktyka, red. B. Krauz-Mozer, P. Borowiec, Kraków 2006, s. 109-110.

51 Vide szerzej M. Rachwał, Demokracja bezpośrednia w procesie kształtowania się społeczeństwa obywatelskiego w Polsce, Warszawa 2010, s. 52-53.

52 Confer Partycypacja spoleczna $w$ samorzadzie terytorialnym - aspekty prawne, ekonomiczne, społeczne, red. K. Głąbicka, P. Śwital, Radom 2016, s. 5-6.

${ }^{53}$ Confer E. Górski, Rozważania o społeczeństwie obywatelskim i inne studia z historii idei, Warszawa 2003, s. 80.

${ }^{54} \mathrm{~W}$ tym miejscu należy zauważyć, że politycy często podejmują działania idące wręcz w przeciwnym kierunku. Partie polityczne nie są zainteresowane aktywizacją społeczną, gdyż w krótko- i średniookresowej perspektywie może być to dla nich niekorzystne oraz stwarzać znaczące ryzyko. Powodem jest wyedukowane społeczeństwo, zniechęcone do ugrupowań znajdujących się na scenie politycznej, które będzie zdolne do stworzenia innych ruchów politycznych. Vide P. Uziębło, Demokracja bezpośrednia i semibezpośrednia, [w:] Demokracja w XXI wieku, red. M. Szyszkowska, Warszawa 2009, s. 107. 
funkcjonowanie partycypacji społecznej wymaga społeczeństwa obywatelskiego. Bez tego ważnego komponentu demokracja partycypacyjna przekształci się prędzej czy później w oligarchię partyjną̧.

\title{
Bibliografia
}

\author{
ŹRÓDŁA
}

„Biuletyn Komisji Konstytucyjnej Zgromadzenia Narodowego” 1995, nr XIV.

Indeks społeczeństwa obywatelskiego w Polsce 2005, Stowarzyszenie Klon/Jawor, Warszawa 2006.

Konstytucja Belgii z dnia 14 lutego 1994 r., thum. W. Skrzydło, Wydawnictwo Sejmowe, Warszawa 1996.

Konstytucja Republiki Butgarii z dnia 12 lipca 1991 r., thum. H. Karpińska, Wydawnictwo Sejmowe, Warszawa 2012.

Konstytucja Republiki Litewskiej z dnia 25 października 1992 r., thum. H. Wisner, Wydawnictwo Sejmowe, Warszawa 2006.

Konstytucja Rzeczypospolitej Polskiej z dnia 2 kwietnia 1997 r., Dz.U. z 1997 r. nr 78, poz. 483, ze zm.

Uchwała Naczelnego Sądu Administracyjnego z 12 grudnia 2005 r., sygn. akt II OPS 4/05, ONSA 2006, nr 2, poz. 37.

Ustawa konstytucyjna z dnia 23 kwietnia 1992 r. o trybie przygotowania i uchwalenia Konstytucji Rzeczypospolitej Polskiej, Dz.U. nr 67, poz. 336, ze zm.

Ustawa z dnia 7 kwietnia 1989 r. Prawo o stowarzyszeniach, Dz.U. z 2019 r. poz. 713, ze zm.

Ustawa z dnia 7 kwietnia 1989 r. o związkach zawodowych rolników indywidualnych, Dz.U. z 2019 r. poz. 210.

Ustawa z dnia 23 maja 1991 r. o organizacjach pracodawców, Dz.U. z 2019 r. poz. 1809.

Ustawa z dnia 23 maja 1991 r. o związkach zawodowych, Dz.U. z 2019 r. poz. 263.

Ustawa z dnia 6 czerwca 1997 r. — Kodeks karny, Dz.U. z 2020 r. poz. 1444, ze zm.

Wyrok Trybunału Konstytucyjnego z 27 maja 2003 r., sygn. akt K 11/03, OTK, nr 5A, poz. 43.

\section{PIŚMIENNICTWO}

André P., Enserink B., Connor D., Public Participation. International Best Practice Principles, IAIA Special Publication Series, nr 4, International Association for Impact Assesment, Fargo 2006.

Davies T., NGOs: A New History of Transnational Civil Society, Oxford University Press, Oxford 2014.

Domańska A., Pozycja ustrojowo-prawna Rzecznika Praw Obywatelskich, Uniwersytet Łódzki, Łódź 2013.

Frączak P., Rogaczewska M., Wygnański K., Głos w dyskusji na temat wizji rozwoju społeczeństwa obywatelskiego w Polsce, maszynopis, Warszawa 2005.

Garlicki L., Polskie prawo konstytucyjne. Zarys wyktadu, Liber, Warszawa 2012.

${ }_{55}$ Confer M. Rachwał, op. cit., s. 53. Vide także M. Tabernacka, op. cit., s. 626-627. 
Górski E., Rozważania o społeczeństwie obywatelskim i inne studia z historii idei, Instytut Filozofii i Socjologii Polskiej Akademii Nauk, Warszawa 2003.

Jaworski L., Wolność prasy i innych środków społecznego przekazu jako zasada ustrojowa Rzeczypospolitej Polskiej, „Zarządzanie Mediami” 2014, t. 1, nr 1.

Kalisiak-Mędelska M., Public Participation in the Municipalities of Polish Voivodeships. A Presentation of the Research Findings, [w:] Social and Economic Development and Regional Politics: Space in a Time of Economic Change, red. P. Hlavacek, P. Olsova, Univerzita Jana Evangelisty, Ústí nad Labem 2013.

Kijowski D.R., Partycypacja obywatelska w samorzadowych procesach decyzyjnych — zagadnienia ogólne, „Samorząd Terytorialny” 2010, nr 1-2.

Ostaszewski K., Partycypacja społeczna $w$ procesie podejmowania rozstrzygnięć $w$ administracji publicznej, Katolicki Uniwersytet Lubelski, Lublin 2013.

Partycypacja społeczna w samorzadzie terytorialnym — aspekty prawne, ekonomiczne, społeczne, red. K. Głąbicka, P. Śwital, Instytut Naukowo-Wydawniczy „Spatium”, Radom 2016.

Piotrowski R., Ochmann P., Pisz M., Prawo konstytucyjne. Kompendium, C.H.Beck, Warszawa 2014.

Pius XI, Encyklika Quadragesimo Anno, [w:] Dokumenty nauki społecznej Kościoła, cz. 1, red. K. Radwan, L. Dyczewski, A. Stanowski, Polski Instytut Kultury Chrześcijańskiej — Fundacja, Lublin 1987.

Potoczek A., Zaufanie spoleczne a proces partycypacji, „Animacja Życia Publicznego. Analizy i Rekomendacje" 2011, nr 2.

Prokop K., Podstawowe zasady ustrojowe, [w:] Prawo konstytucyjne, red. S. Bożyk, Temida2, Białystok 2014.

Pułło A., Zasady ustroju politycznego państwa. Zarys wykładu, Gdańska Szkoła Wyższa, Gdańsk 2014.

Rachwał M., Demokracja bezpośrednia w procesie ksztattowania się społeczeństwa obywatelskiego w Polsce, Wydawnictwo Sejmowe, Warszawa 2010.

Rzepliński A., Wprowadzenie, [w:] Prawa człowieka w społeczeństwie obywatelskim, red. A. Rzepliński, Helsińska Fundacja Praw Człowieka, Warszawa 1993.

Stach Ł., Społeczeństwo obywatelskie Johna Keane'a, [w:] Czas społeczeństwa obywatelskiego. Między teoria a praktyka, red. B. Krauz-Mozer, P. Borowiec, Uniwersytet Jagielloński, Kraków 2006.

Tabernacka M., Bezpośredni udziat obywateli w kształtowaniu rozstrzygnięć władz publicznych $w$ postepowaniu mediacyjnym $w$ sferze administracji publicznej jako element funkcjonowania społeczeństwa obywatelskiego, [w:] Prawna działalność instytucji społeczeństwa obywatelskiego, red. J. Blicharz, J. Boć, Uniwersytet Wrocławski, Wrocław 2009.

Uziębło P., Demokracja bezpośrednia i semibezpośrednia, [w:] Demokracja w XXI wieku, red. M. Szyszkowska, Uniwersytet Warszawski, Warszawa 2009.

Winczorek P., Komentarz do Konstytucji Rzeczypospolitej Polskiej z dnia 2 kwietnia 1997 r., Liber, Warszawa 2000. 